European Journal of Business and Innovation Research

Vol.8, No.2.pp. 30-47, April 2020

Published by ECRTD-UK

Print ISSN: 2053-4019(Print), Online ISSN: 2053-4027(Online)

\title{
CORPORATE GOVERNANCE PRACTICES AND LABOUR PRODUCTIVITY OF NIGERIAN LISTED FIRMS BETWEEN 1989 AND 2018
}

\author{
Abraham Oketooyin Gbadebo (Ph.D.) \\ Department of Banking and Finance, \\ Osun State University,_Osogbo, Osun State \\ Postal address: GPO Box 31360, Dugbe, Ibadan, Oyo State, Nigeria
}

\begin{abstract}
The study examined the linkage between corporate governance practices and labour productivity of Nigerian listed firms between 1989 and 2018. The paper adopted panel data technique to establish the relationship between dependent and independent variables. Hausman test result revealed that Fixed Effect is the most appropriate estimator due to firms' differences. The panel regression result revealed that three out of the independent variables (board size, block holding and firm size have positive and significant relation with labour productivity of listed firms in Nigeria. Only leverage has an inverse correlation with the dependent indicators, while directors' shareholding, board independence and independent audit committee have positive but insignificant linkage with labour productivity of listed firms in Nigeria. The study showed that an increase in board size influences the productivity of Nigerian firms positively but at a decreasing rate, indicating an optimal size, hence the relationship between the two variables is quadratic in nature. In addition, increase in institutional investors and firm size enhance dependent variables. On the other hand, an increase in borrowing leads to decline in productivity. However, directors' shareholding, independent directors and independence of audit committee do not have influence on the dependent variable measured by labour productivity. This paper contributes to the body of knowledge by extending the number of years covered by this study to thirty as against the average of ten years by previous studies. Labour productivity was also used as a measure of performance, which is not common among the emerging economies scholars including Nigeria
\end{abstract}

KEYWORDS: Governance, productivity emerging economies

JEL: C33, G38, L25

\section{INTRODUCTION}

The main objective of setting up different code of corporate governance is to proffer permanent solutions to the problem of adverse selection and moral hazard between the principal and the agent. According to Senbet and John (1998) "corporate governance entails the procedure where all stakeholders within an organisation are able to put their resources together with a view to curtailing the excesses of managers and other insiders in order to protect the interest of the stakeholders. In recent time the term stakeholders have been extended beyond the shareholders alone but to include others such as the creditors, employees, government and conservationists.

The importance of high productivity in enhancing economic growth and standard of living of people has been established by scholars (Hassan, 2014). Hassan, (2014) observed that there is no universally acceptable definition of productivity. However, it has been described by economists as a ratio of output to input over a period of time (Roslas, 1948). Business managers on the other 
hand defined productivity as a measure of efficiency and effectiveness and performance of individual company (Udo-Aka 1983).

Commonly, well-governed firms are expected to have better performance with less stress, higher share price, and consistent dividend policy to the shareholders inform of cash pay-out and capital appreciation; while poorly-governed firms are to experience the opposite (Kyereboah-Coleman \& Biekpe, 2006). Many studies have established the significance of good corporate governance for the improvement of companies' performance (Ahmad \& Sallau, 2018; Gbadebo, 2017; Hamidu, \&Modibbo, 2015; Uwuigbe, Peter, \& Oyeniyi, 2014; (Adewuyi \& Olowookere, 2009; Olowookere 2008; ;Adelegan, 2007; Magbagbeola, 2006; Sanda, Mukailu \& Garba 2005; Adenikinju \& Ayonrinde, 2001, Brown \& Caylor, 2005; Core \& Rusticus, 2005, etc). On the other hand several others have expressed the weaknesses of some corporate governance indicators (Ahmad \& Sallau, 2018; Gbadebo, 2017; Chidambaran, Palia Zheng 2007; Core, Guay \& Rusticus 2005; Adenikinju, 2005 and Demsetz \& Lehn, 1985,).

The present work contributes to the literature by extending the period of study to cover the period (1989-2018), that is 30 years, which is more than any other previous empirical study in Nigeria, for example Abu (2016) 10 years, Adebiyi (2017) 11 years and Moses (2019) 10 years. Secondly, this study covered pre- and post- code of corporate governance code of 2003. Consequently, the impact of the code can be compared with the period when the code was not in existence. Lastly, the study is an attempt to address some of the shortcomings of financial performance indicators (ROA, ROE, ROCE, EPS and Tobin's Q), which include the problem of selection of depreciation method and differences in accounting methods when pre-tax income is used as denominator. It also affects the value of the denominator of typical financial performance proxies (Hill \& Snell, 1989 and Hay \&Morris 1979). Therefore the use of productivity helps to validate the correctness of profitability ratios as measure of performance.

To the best knowledge of the researcher, there is scanty empirical research (Olowookere, 2008 and Adewuyi and Olowookere, 2009) that analyzes directly the relationship between governance and productivity of firms based in Nigeria. Given that productivity increases, it influences financial performance positively, the limited empirical evidence of the effect of corporate governance on financial performance in the region indicates an expected positive relationship. Therefore this study examines the relationship between corporate governance practices and firm performance in Nigeria. Specifically, the study sets out to:

$>\quad$ evaluate the relationship between board size and labour productivity of Nigerian listed firms;

$>\quad$ appraise the relationship between non-executive directors and labour productivity of Nigerian listed firms;

$>\quad$ examine the relationship between director shareholding and labour productivity of Nigerian listed firms;

$>\quad$ assess the association between independence of audit committee and labour productivity of Nigerian listed firms; 
European Journal of Business and Innovation Research

Vol.8, No.2.pp. 30-47, April 2020

Published by ECRTD-UK

Print ISSN: 2053-4019(Print), Online ISSN: 2053-4027(Online)

$>\quad$ evaluate the relation between block holding and labour productivity of Nigerian listed firms;

$>\quad$ evaluate the relation between debt owed to leverage and labour productivity of Nigerian listed firms; and

$>\quad$ evaluate the relation between firm size and labour productivity of Nigerian listed firms.

In other to achieve the objectives of the study, the following hypotheses stated in their null form were tested:

Hypothesis 1: There is no significant relationship between board size and labour productivity of Nigerian listed firms;

Hypothesis 2: There is no significant link between non-executive directors and labour productivity of Nigerian listed firms;

Hypothesis 3: There is no significant association between director shareholding and labour productivity of Nigerian listed firms;

Hypothesis 4: There is no significant association between independence of audit committee and labour productivity of Nigerian listed firms;

Hypothesis 5: There is no significant relationship between block holding and labour productivity of Nigerian listed firms;

Hypothesis 6: There is no significant correlation between leverage and labour productivity of Nigerian listed firms; and

Hypothesis 7: There is no significant association between firm size and labour productivity of Nigerian listed firms.

The rest of the paper is arranged thus: section two captures empirical reviews of past literature while section three shows the methodology. Section four comprises the results of findings and discussions, and section five summaries the work, and also concludes with some policy implications.

\section{CONCEPTUAL/THEORETICAL UNDERPINNING/LITERATURE REVIEW}

\section{Conceptual Issues}

\section{Corporate Governance}

Corporate organisations have become major actors in the political economy of many countries. Under the current neo-liberal economic philosophy, they are regarded as the engine of growth and development. Based on this premise, the performance of these organisations are of interest to both the government and the citizens. Essentially, various measures, models and concepts have been developed globally and nationally to ensure that these corporate organisations not only survive but operate in the best interest of all stakeholders including the government. One of the most important concepts recently developed by business and financial experts is corporate governance (Sanusi, 2002).

For over two decades, the concept of corporate governance has been identified as key to the survival of business corporations the world over. This is better expressed by a former Governor of the Central Bank of Nigeria, Sanusi (2002) thus: "Issues of corporate governance have become so pervasive in recent years and the lessons learned from experiences of corporate organsiations have become major actors in the political economy of many countries. Under the current neo-liberal 
European Journal of Business and Innovation Research

Vol.8, No.2.pp. 30-47, April 2020

Published by ECRTD-UK

Print ISSN: 2053-4019(Print), Online ISSN: 2053-4027(Online)

economic philosophy, they are regarded as the engine of growth and development. Based on this premise, the performance of these organisations is of interest to both the government and the citizens".

Moreover, it is important to recognise that economic performance of any country is shaped largely by the quality and effectiveness of the nation's corporate governance. Thus, the world over, sound corporate governance has become major concern not only to business enterprises, but also to central banks and governments. It is worthy of note that the great value corporate governance has in recent years created an unimaginable surge around the world. This is also evident on the continent of Africa in the number of national corporate governance reports that have been produced and published within a close range (Rossouw, 2005).

Wilson (2006) explained that no company whatsoever can be too big financially or otherwise to fail if the practice of good corporate governance is jettisoned. In his words:

"The clear lesson The Enron, Parmalat, World Com, Barings Bank taught the corporate world was that no company or bank can be too big financially or otherwise to fail. A common strand that ran through these monumental corporate failures was the poor corporate governance culture, to wit, poor management, poor regulation and poor supervision. As such, events on the global marketplace have clearly defined the position of corporate governance as the heart of business corporations if they actually desire to stay in businesses" (Wilson, 2006).

\section{Productivity Concept}

Productivity is commonly defined as a ratio of a volume measure of output to a volume measure of input use. While there is no disagreement on this general notion, a look at the productivity literature and its various applications reveals very quickly that there is neither a unique purpose for nor a single measure of productivity (OECD 2001)

Company-level productivity measures are other ways to provide a more comprehensive gauge of firm performance than profit rates using public financial data. This is the process of gauging the efficiency with which inputs are converted to useful outputs. Productivity corresponds to the total economic value created by the capital or labour employed within the enterprise. If productivity rises over time, additional value is created and economic wealth grows.

Labour productivity is the most common productivity measure, partly because it is the easiest to compute. Labour productivity corresponds to output per unit of labour input (or value-added per worker-hour, as computed in this study). Labour productivity at the level of the economy as a whole provides an indicator of a nation's real income per capita, or average economic welfare. Economic theory and past research findings lead to expectation that:

* Capital and labour inputs should have certain quantitative relationships with output, reflecting typical production function relationships.

* Labour productivity is a function of capital inputs, so firms with higher levels of capital will tend to have higher labour productivity. This should lead to a positive correlation between 
Vol.8, No.2.pp. 30-47, April 2020

Published by ECRTD-UK

Print ISSN: 2053-4019(Print), Online ISSN: 2053-4027(Online)

fixed assets per person and value-added per person, provided that the fixed assets variable is a reasonably good proxy for firms' capital stock.

* Profitability and labour productivity are likely to be positively correlated: firms that are more productive should be more profitable, all other things being equal.

* . If there are economies of scale, labour productivity (and possibly profits per person) will be positively correlated with firm size.

* Labour productivity and profitability are likely to be positively correlated with the skill level of the workforce. In terms of the current dataset, this means that the average worker fixed effect and the average age of the workforce should be positively correlated with value-added and profits. We interpret them as proxy measures of the human capital of each firm's workforce.

* The average wage per employee is expected to be positively correlated with labour productivity (because if the marginal product of labour is higher in more productive firms, wages should also be higher). The average wage per employee may also be correlated with firm profitability

\section{THEORETICAL UNDERPINNING}

The challenge of principal-agent arises when a principal compensates an agent for performing a particular act that is useful to the principal and costly to the manager, leading to performance that is expensive to observe. It is the case to some extent for all contracts that are written in a world of information asymmetry, uncertainty and risk (see figure 1.1

Figure 1.1: Basic idea of Agency Theory

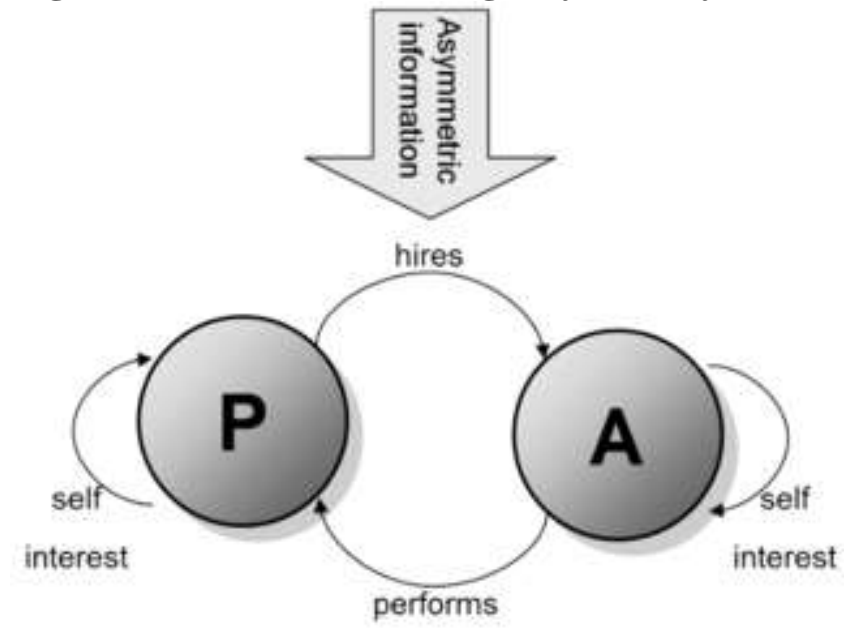

(Note: P: Principal, A: Agent)

Source: Eisenhardt, (1989)

Several theories were propounded to avert this problem. These include a plan combining the efficiency compensation and monitoring, a revenue sharing plan, a forcing-contract plan and the use of economic tournament, among others (Schotter, 2001). The concept of corporate governance looks at the best approach to solving the problem of adverse selection and moral hazard attendant 
European Journal of Business and Innovation Research

Vol.8, No.2.pp. 30-47, April 2020

Published by ECRTD-UK

Print ISSN: 2053-4019(Print), Online ISSN: 2053-4027(Online)

on principal-agent issues. Recently, a keen attention accorded this concept following scandals witnessed in Adelphia, Enron, and WorldCom.

Corporate governance involves how all stakeholders in the firm attempt to ensure that managers and other insiders adopt gauges that protect the interests of the stakeholders (Senbet and John, 1998). In recent times, the term stakeholder means more that what it used to be; it goes beyond its traditional treatment as it is to include shareholders, employees, creditors, government and others, for instance, environmentalists.

\section{LITERATURE REVIEW}

\section{Dependent Variable}

\section{Labour Productivity}

Some scholars that have used labour productivity as measure of firms' performance include: Munddakkad (2018) for India, Gaitán, Herrera, and Pablo (2017) for Latin America Li, (2016) for Japan, Girma and Veneappa, (2015) for India, Avarmaa, Hazak and Mannasoo (2013) for Baltic countries, Buera and Shin, (2013), for Latin America, Tian and Twite (2011) Australian, Ghosh (2009) for India, Nunes, (2007) for Portugal, Gatti and Love (2006) for Bulgaria, Kioke (2001) for Germany, Renneboog (2000) for Belgium, Schiantarelli and Sembenolli (1997) for United Kingdom

\section{Relationship between Dependent and Independent Variables}

\section{Board Size and Firms' Productivity}

The studies of K"oke, (2001) for Germany, Dalton Daily, Johnson, \& Ellstrand, (1999) for Tunisia, revealed a positive association between board size and labour productivity though for a short while. They concluded that there is a non-linear quadratic relationship between board size and productivity since an increasing number of board members affects productivity positively but at a decreasing rate, suggesting an optimal size. Conversely, Yermack (1996) confirmed that board size is negatively correlated with firm value. However, Adewuyi and Olowookere (2009) and Olowookere (2008) both for Nigeria that ever used productivity to best of researcher's knowledge observed an insignificant relationship between board size and productivity.

\section{Independent Directors/Non-executive directors and Firms' Productivity}

Gaitán, Herrera, and Pablo (2017) for Latin America, Shan and McIver, (2011) for China, Reddy, Locke, Scrimgeour, \& Gunasekarage (2008) for New Zealand and Olowookere, (2008) for Nigeria found a positive correlation between board independence and productivity. Conversely, Xu, \& Wang, (1999) for China observed a negative influence between board independence and labour productivity. However, Gbadebo (2016) for Nigeria, Adewuyi et al (2009) for Nigeria observed an insignificant association between the two indicators. 
European Journal of Business and Innovation Research

Vol.8, No.2.pp. 30-47, April 2020

Published by ECRTD-UK

Print ISSN: 2053-4019(Print), Online ISSN: 2053-4027(Online)

\section{Directors' Shareholding and firms' Productivity}

Tian and Twite (2011) for Australian, Min and Smyth (2014) discovered that stock-based compensation improve firm's productivity. However, Adewuyi et al (2009) and Olowookere (2008) observed an insignificant relationship between Directors' Shareholding and firms' Productivity.

\section{Independence of audit committee and firms' Productivity}

Olowookere, (2008) for Nigeria observed inverse relationship between independent and dependent variables. while Adewuyi et al (2009) for Nigeria claimed an insignificant correlation between the two variables.

\section{Block Holders' / Institutional Investors and Firms' Productivity}

Gaitán et al, (2017) for Latin America, Mnasri and Ellouze (2015) for Tunisia, Chen, Du, Li, \& Ouyang (2013), Shan and McIver (2011) for China, Rubin and Smith, 2009, Reddy et al. (2008), Adewuyi and Olowookere (2009) for Nigeria and K"oke, (2001) for Germany, found a positive significant correlation between block holders and firm productivity. However, Olowookere (2008) for Nigeria revealed an insignificant association between Block Holders and firms Productivity.

\section{Leverage and Firms' Productivity}

Mundakkad, (2018) examined the relationship between leverage and labour productivity in India and found negative significant correlation among the two variables. The findings was supported by, Avarmaa, Squera and Serraqueiro, (2013) for Baltic countries, Khan and Thomas (2013) for Pakistan, Buera and Shin (2013) for Latin America, Coircelli, Driffield, Pal and Isabelle, (2012) for Central and Eastern Europe, Arellano, Yan and Jing (2012), Ghosh (2009) for India, Tian and Twite (2011) for Australian, Adewuyi et al (2009), and Olowookere, (2008) both for Nigeria, Nunes, (2007) for Portuguese, Kioke 2001 for Germany, Renneboog, (2000) for Belgium Schiantarelli and Sembenelli (1997) for United Kingdom, Nickell and Nicolitsas, (1999) for United Kingdom. On the other hand, studies Li (2016) for Japan,, Girma and Vencappa (2015) Buera and Yongseok (2013), Gatti and Love (2006) for Bulgaria, Musso and Schiavo (2008) for France Nucci, Pozzolo and Schivardi (2005) for Italy, Cooley and Quadrini (2001) allow borrowing capacity to rise with increase in productivity. Contrarily, Mundakkad, (2018) observed that that leverage do not increase productivity at the low levels of productivity however medium and higher productivity firms, leverage tend to increase the productivity therefore the relationship between leverage and labour productivity is non-monotonic that is increase in leverage adversely affect the productivity of less productive firms.

\section{Firm Size and firms' Productivity}

Leung, Meh, and Terajima (2008b) for Canada found a positive correlation between firm size and labour productivity while Olowookere (2008) observed negative relation with labour productivity. However, Tian et al (2011) for Australian and Adewuyi et al (2009) for Nigeria claimed that there is no association between firm size and productivity. 
European Journal of Business and Innovation Research

Vol.8, No.2.pp. 30-47, April 2020

Published by ECRTD-UK

Print ISSN: 2053-4019(Print), Online ISSN: 2053-4027(Online)

\section{METHODOLOGY}

An ex-post facto research design was adopted to investigate the relationship between corporate governance variables and performance measured productivity based of listed firms in Nigeria. Secondary data were collected from forty three (43) companies selected out of one hundred and sixty nine (169) companies listed on the Nigerian Stock Exchanges at December $31^{\text {st }} 2018$ using annual financial statements and Nigeria Stock Exchange (NSE) Factbooks various issues. Out of population of 169 firms as at December $31^{\text {st }} 2018$ only about 97 companies were listed as at 1990. Effectively the population of this study was 97 firms while 72 companies that were registered after 1990 were dropped. Consequently, that is over $44 \%$ of the population and $72 \%$ in value of the firms that were incorporated on or before 1990 and submitted their financial statements to SEC for the period under review. The study adopted judgmental sampling technique. This is a sampling method that allows the researcher to pick on any member of the population based on his experience. This is consistent with the propositions of Krejcie \& Morgan (1970) where a minimum of 5\% of a defined population is considered as an appropriate sample size in making generalisation. The choice of the selected firms was occasioned by the nature and extent of corporate failures and scandals that have bedeviled the industries overtime.

\section{Model Specification}

In line with all the specific objectives, the model specification is to examine labour productivity as a performances indicator in Nigeria. Mousa, \& Desok (2012) model that related firm performance with some indicators of corporate governance as well as firm characteristics variables is given as:

$$
F P_{i t}=\alpha+\beta C G O V_{i t}+\gamma X_{i t}+\varepsilon_{i t}
$$

where FP is a measure of firm performance, $\mathrm{CGOV}$ is a vector of Corporate Governance; $\mathrm{X}$ is a set of enterprise characteristics variables. Firm productivity as a measure of performance is to be captured by Labour Productivity, which is in line with Olowooker (2008) and Gupta (2015). Corporate Governance indicators used in this study are (i) Board Size; (ii) Outside Board Directors; (iii) Directors' Shareholding; (iv) Block Holders; and (v) Independence of Audit Committee. The Firm Characteristics (X) in the model are (i) Leverage; and (ii) Firm Size, The error term is represented by $\varepsilon$, subscript $i$ stand for individual firm and $t$ is time period.

The particular model, therefore, is specified explicitly as:

$$
\begin{gathered}
F P_{i t}=\alpha+\beta_{1} B S_{i t}+\beta_{2} O B D_{i t}+\beta_{3} D S H_{i t}+\beta_{4} B H_{i t}+\beta_{5} I A C_{i t}+\gamma_{1} L_{i t}+\gamma_{2} F S_{i t} \\
+\varepsilon_{i t}
\end{gathered}
$$

The variables are as previously defined. Meanwhile, $\varepsilon_{i t}$ consists of two error components as:

$$
\varepsilon_{i t}=\lambda_{i}+v_{i t}
$$

$L P_{i t}=\alpha+\beta_{1} B S_{i t}+\beta_{2} O B D_{i t}+\beta_{3} D S H_{i t}+\beta_{4} B H_{i t}+\beta_{5} I A C_{i t}+\beta_{6} B S^{2}{ }_{i t}+\gamma_{1} L_{i t}+\gamma_{2} F S_{i t}+$

$\lambda_{i}+v_{i t}$

Where: $B S^{2}$ is square of board size 
European Journal of Business and Innovation Research

Vol.8, No.2.pp. 30-47, April 2020

Published by ECRTD-UK

Print ISSN: 2053-4019(Print), Online ISSN: 2053-4027(Online)

Table 1: Definition of operative variables

\begin{tabular}{|c|c|c|c|c|c|}
\hline $\mathbf{S} / \mathbf{N}$ & Variables & Definition & Type & Measurement & Supporting Scholars \\
\hline \multicolumn{6}{|l|}{1} \\
\hline 1 & LP & Labour Productivity & Dependent & $\begin{array}{l}\text { Fixed assets } \\
\text { divided by number } \\
\text { of employees }\end{array}$ & $\begin{array}{l}\text { Hassan, 2018, Gbadebo } \\
2017, \text { Li, 2016, Gupta, } \\
2002\end{array}$ \\
\hline 2. & $\mathrm{BS}$ & Board size & Independent & $\begin{array}{l}\text { Number of } \\
\text { directors on board } \\
\text { both the executive } \\
\text { and non-executive }\end{array}$ & $\begin{array}{l}\text { Yermark, } 1996 \text { Dalton et.al. } \\
1999 \text { Olowookere } 2008 \& \\
\text { Gbadebo, } 2017\end{array}$ \\
\hline 3. & OBD & Outside Board Directors & Independent & $\begin{array}{l}\text { The ratio of outside } \\
\text { directors to internal } \\
\text { directors }\end{array}$ & $\begin{array}{l}\text { Gaitan et al. 2017, } \\
\text { Gbadebo, 2016, Shan et al, } \\
2011, \\
\text { Xu et al } 1999 \text { Reddy et al } \\
2008\end{array}$ \\
\hline 4. & $\mathrm{DSH}$ & Directors' Shareholding & Independent & $\begin{array}{l}\text { Percentage of total } \\
\text { shares owned by } \\
\text { the directors }\end{array}$ & $\begin{array}{l}\text { Gaitan et al, } 2017 \\
\text { Min et al. 2014, Tian et al, } \\
2011\end{array}$ \\
\hline 5 & $\mathrm{BH}$ & Block Holders & Independent & $\begin{array}{l}\text { Substantial } \\
\text { shareholders with } \\
5 \% \text { and above } \\
\text { shareholding } \\
\end{array}$ & $\begin{array}{l}\text { Gaitan et al, } 2017 \\
\text { Mnnasri et al } 2015 \\
\text { Rubin et al 2009, K'oke, } \\
2001\end{array}$ \\
\hline 6 & IAC & $\begin{array}{l}\text { Independence of Audit } \\
\text { Committee }\end{array}$ & Independent & $\begin{array}{l}\text { Members of Audit } \\
\text { committee that are } \\
\text { not on Board }\end{array}$ & $\begin{array}{l}\text { Adewuyi et al 2009, } \\
\text { Olowookere } 2008\end{array}$ \\
\hline 7. & $\mathrm{FS}$ & & Independent & Log of Total Asset & $\begin{array}{l}\text { Tian et al 2011, Leung, } \\
2008 \mathrm{a}\end{array}$ \\
\hline 8. & $\mathrm{~L}$ & & Independent & $\begin{array}{l}\text { Ratio of Debt to } \\
\text { Share Capital }\end{array}$ & $\begin{array}{l}\text { Mundakkad, } \\
\text { Gbadebo, 2017, } \\
\text { Buera, 2013, Tian et al, } \\
\text { 2011 Musso et al. 2008, }\end{array}$ \\
\hline
\end{tabular}

Source: Author's computation 2020

\section{RESULTS AND FINDINGS}

Descriptive analysis

Table 2: Measures of Firms' Performance (Dependent Variable)

\begin{tabular}{|c|c|c|c|c|c|c|}
\hline Variables & Mean & Std. dev & Min & Max & & \\
\hline $\begin{array}{c}\text { Labour } \sim \text { overall } \\
\text { Between } \\
\text { Within }\end{array}$ & 5425.026 & $\begin{array}{l}11732.47 \\
6672.471 \\
9701.825\end{array}$ & $\begin{array}{l}-12780.03 \\
659.9623 \\
-28222.94\end{array}$ & $\begin{array}{l}122891 \\
34008.28 \\
94307.73\end{array}$ & $\begin{array}{l}\mathrm{N}= \\
\mathrm{n}= \\
\mathrm{T}=\end{array}$ & $\begin{array}{r}1118 \\
43 \\
26\end{array}$ \\
\hline
\end{tabular}

Source: computed by author with stata 14 software package 
Print ISSN: 2053-4019(Print), Online ISSN: 2053-4027(Online)

The summary statistics of dependent variable shows that the labour productivity average is 5425.026 while the standard deviation is 11732.47 . The value of the standard deviation indicates that there is wide spread in the performance of firms in Nigeria as reflected in labour productivity. This is also evident in the wide gap between the maximum and minimum values. For example, the maximum value of labour productivity is $122,891.00$ while the minimum is $-12,780.03$, with difference of 135671 . This performance variation is rather on the high side. It is equally observed that within a firm, performance varied widely over time. For instance, labour productivity is 9701.825. The maximum value within a given firm over time for labour productivity variable is 94307.73, while the minimum value is -28222.94 . The wide variation over time indicates high level of fluctuation of the business environment, which affects the performance of business.

Table 3: Measures of Corporate Governance (Independent Variables)

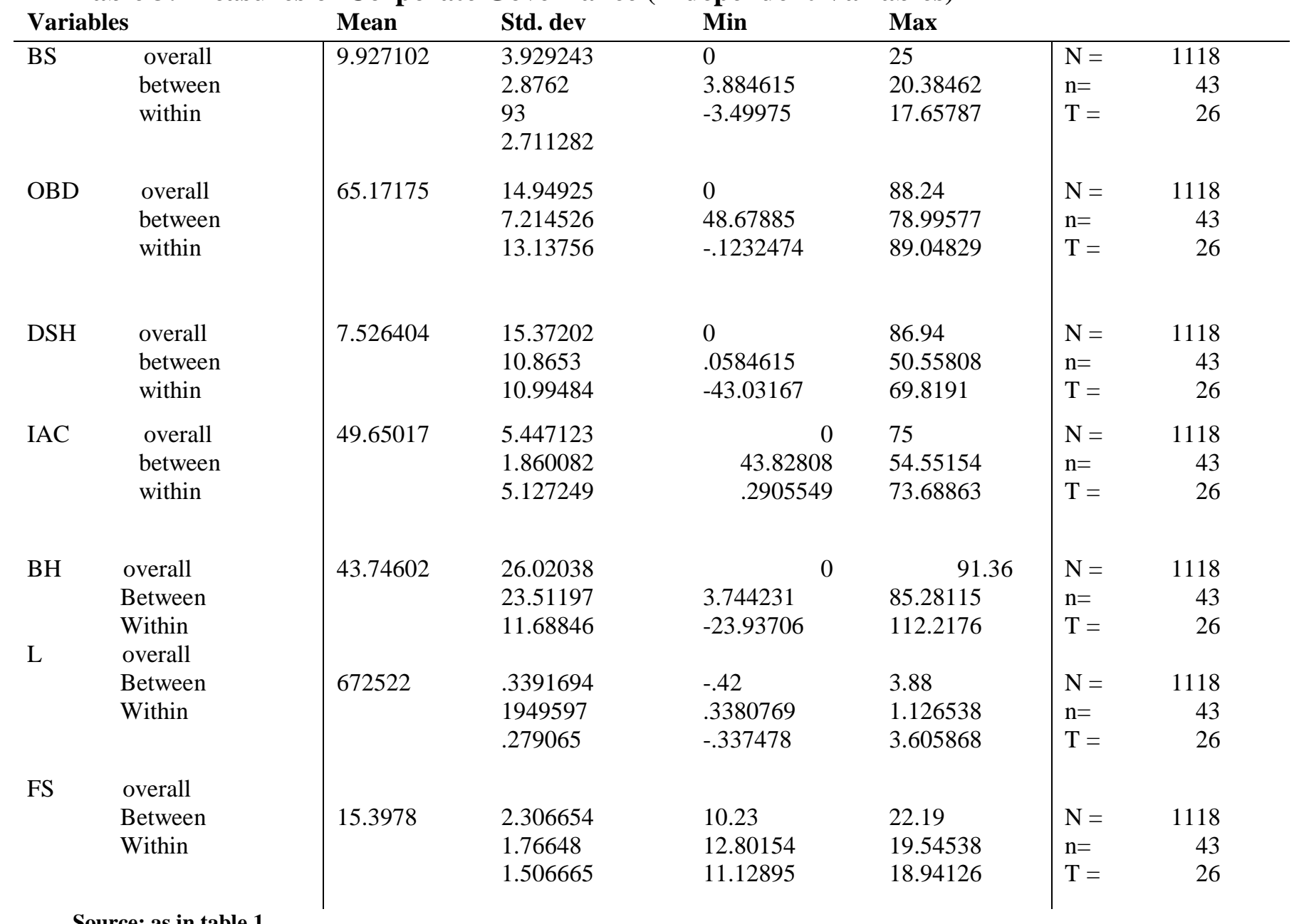

The independent variables are various indicators of corporate governance mechanisms which include board size, outside board directors, directors' shareholding, independent audit committee, block holding, leverage and firm size. The summary statistics show that on the average the board 
Vol.8, No.2.pp. 30-47, April 2020

Published by ECRTD-UK

Print ISSN: 2053-4019(Print), Online ISSN: 2053-4027(Online)

size, outside board directors and directors shareholdings are 9.9217, 65.1718 and 7.5264 respectively while that of independent audit committee, block holding, leverage and firm size are 49.6502, 43.7460, 0.6713 and 15.3978 correspondingly. The standard deviation of gauges of corporate governance mechanisms are 3.9292, 14.9493, 15.3702 and 5.4471 for board size, outside board directors, directors shareholding and independent audit committee while block holding, leverage and firm size posted 26.0204, 0.3392 and 2.3067 correspondingly. It is also noted that the identified corporate governance mechanisms are diverse over time. For example the minimum for board size, outside board directors, directors' shareholding, independent audit committee and block holding is zero (0) while leverage and firm size have -0.42 and 10.33 respectively as their minimum. On the other hand, the maximum for board size, outside board directors, directors' shareholding and independent audit committee are: $25,88.24 \%, 86.94 \%$ and $75 \%$ correspondingly while block holding, leverage and firm size recorded 91.36, 3.88 and 22.19 respectively

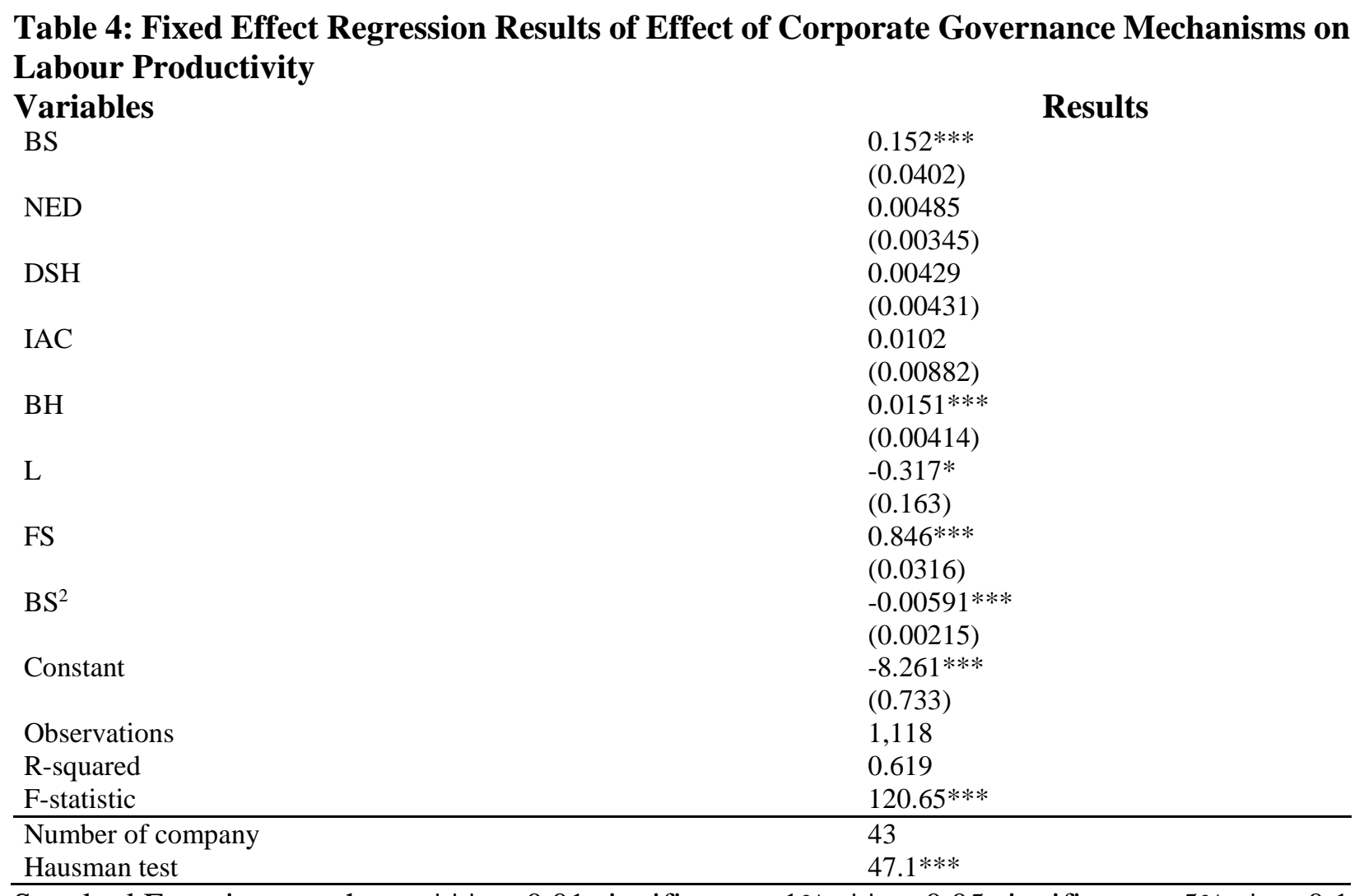

Standard Error in parentheses, ${ }^{* * *} \mathrm{p}<0.01$ significant at $1 \%,{ }^{* *} \mathrm{p}<0.05$ significant at $5 \%,{ }^{*} \mathrm{p}<0.1$ Significant at $10 \%$

Source: as in table 4.1

The effect of Corporate Governance on labour productivity of Nigerian listed firms is presented in Table 4 The coefficient of determinant $\mathrm{R}^{2}$ for the selected firms is 0.619 or $62 \%$ which shows that the selected corporate governance mechanisms jointly and severally explained about $62 \%$ of the changes in labour productivity of the Nigerian listed firms, while only about $38 \%$ variance is not 
European Journal of Business and Innovation Research

Vol.8, No.2.pp. 30-47, April 2020

Published by ECRTD-UK

Print ISSN: 2053-4019(Print), Online ISSN: 2053-4027(Online)

explained by the independent variables. The model for the sampled firms indicates that it is of a good fit.

From the sampled firms, the Board size (BS) is positively and statistically significant at $1 \%$ while square of Board size $\left(\mathrm{BS}^{2}\right)$ is negatively statistically significant at the level of $1 \%$. This shows that an increase in board membership will continue to enhance performance measure by labour productivity up to a certain extent thereafter, it will start declining. This equally confirms that BS does not have a linear relationship with firm performance measured by labour productivity rather a quadratic relationship. Also, Block Holding $(\mathrm{BH})$ is positively statistically significant at $1 \%$ level of significance. It reveals that an increase in Block Holding will lead to an improvement in performance measured by labour productivity. Similarly, Firm size (FS) as a measure of corporate governance indicator is positively significant at $1 \%$. This reflects that as the firm size increases the performance level measured by labour productivity will continue to rise. However, leverage (L) is negatively statistically significant at $10 \%$ level of significance. It shows that an increase in the level of long term debt compared with equity will result into decrease in the firm performance gauged by labour productivity.

Board size still exerts an inverted U shape effect on firms' labour productivity. On the other hand, block holding and firm size enhances higher labour productivity. However, leverage reduces the level of labour productivity. This may be due to financial friction by firms that is, the difference between the return businesses earned from plants and equipment and the market cost of capital. Board size, block holding, firm size and leverage with $p$ value of 0.01 the first three variables and $\mathrm{p}$ value of 0.1 for the fourth indicator are statistically significant, thus null hypothesis $\left(\mathrm{H}_{0}\right)$ for each of these variables should be rejected. Meanwhile alternative hypotheses $\left(\mathrm{H}_{1}\right)$ should be accepted for non-executive directors, directors' shareholding and independent audit committee when labour productivity is used as a measure of performance for the Nigerian listed firms.

\section{DISCUSSION OF FINDINGS}

This study found a positive and significant relationship between board size and labour productivity of Nigerian listed firms. The research also observed a non-linear quadratic relationship between the two variables since an increasing number of board members affects productivity positively but at a decreasing rate, suggesting an optimal size. This result is consistent with the findings of Gbadebo (2017 and 2016) for Nigeria, Koke 2001 for Germany and Dalton Daily, Johnson, \& Ellstrand, (1999) for Tunisia. Conversely, Yermack (1996) confirms that board size is negatively correlated with firms value using labour productivity as a gauge. However, Adewuyi and Olowookere (2009) and Olowookere (2008) both for Nigeria observed an insignificant relationship between board size and productivity. Thus, null hypothesis $\left(\mathrm{H}_{0}\right)$ should be rejected.

The result also revealed that block holding have a positive significant relationship with labour productivity of Nigerian listed firms. This indicates that as the number of institutional shareholders' increases, firm performance measured by labour productivity improves. This result is supported with the works of Gaitán et al, (2017) for Latin America, Mnasri and Ellouze (2015), Chen, Du, Li, \& Ouyang (2013), Shan and McIver (2011), and Rubin and Smith, 2009, Reddy et 
European Journal of Business and Innovation Research

Vol.8, No.2.pp. 30-47, April 2020

Published by ECRTD-UK

Print ISSN: 2053-4019(Print), Online ISSN: 2053-4027(Online)

al. (2008). Adewuyi and Olowookere (2009) and K"oke, (2001), found a negative significant correlation between block holding and firm productivity. Nevertheless, Olowookere (2008) revealed an insignificant association between Block Holding and firms Productivity. Consequently, null hypothesis $\left(\mathrm{H}_{0}\right)$ should be rejected.

Furthermore, the study that observed Firm size has a positive significant relationship with labour productivity of Nigerian listed firms. This outcome was confirmed by Leung, Meh, and Terajima (2008b). This is contrary to Olowookere, (2008) who detected a negative correlation between dependent and independent variables. However, Tian et al (2011) and Adwuyi et al (2009) found no significant association between the two variables. Therefore, null hypothesis $\left(\mathrm{H}_{0}\right)$ should be rejected.

Moreover, Leverage has a negative significant association with labour productivity of Nigerian listed firms. This finding is corroborated by Gopinath, Sebnem, Midrigan and Xu (2014) for Taiwan, Avarmaa, Squera and Serraqueiro, (2013) for Baltic countries, Khan and Thomas (2013) for Pakistan, Buera and Shin (2013) for Latin America, Coircelli, Driffield, Pal and Isabelle, (2012) for Central and Eastern Europe, Arellano, Yan and Jing (2012), Ghosh (2009) for India, Tian and Twite (2011) for Australian, Adewuyi et al (2009), and Olowookere, (2008) both for Nigeria. On the other hand, recent studies such as Mundakkad (2018), Li (2016), Girma and Vencappa (2015) Buera and Yongseok (2013), Gatti and Love (2008) for Bulgaria, Musso and Schiavo (2008) for France Nucci, Pozzolo and Schivardi (2005) for Italy, Cooley and Quadrini (2001) discovered that borrowing capacity of firms rises with increase in productivity. Hence, null hypothesis $\left(\mathrm{H}_{0}\right)$ should be rejected.

The study further discovered a positive but insignificant influence between Directors' Shareholding and Labour Productivity of Nigerian listed Firms. This is in tandem with the findings of Adewuyi et al (2009) and Olowookere (2008) both for Nigeria. Conversely, Tian and Twite (2011) for Australian, Min and Smyth (2014) discovered a positive relation between the two indicators. Therefore, alternative hypothesis $\left(\mathrm{H}_{1}\right)$ should be accepted.

This work also revealed a positive but insignificant influence between independence of audit committee and Labour Productivity of Nigerian listed Firms. This is contrary to the studies of Olowookere, (2008) and Adewuyi et al (2009) both for Nigeria, who observed inverse relationship between the independent and dependent variables. Consequently, alternative hypothesis $\left(\mathrm{H}_{1}\right)$ should be accepted.

Lastly, the study showed a positive but insignificant influence between independent directors and Labour Productivity of Nigerian listed Firms. This is inversely related with the findings of Gaitán, Herrera, and Pablo (2017) for Latin America), Shan and McIver (2011) for China, Reddy, Locke, Scrimgeour, \& Gunasekarage (2008) for New Zealand and Olowookere, (2008) for Nigeria, who found a positive correlation between independent board and productivity. However, Xu, \& Wang, (1999) for china observed a negative influence between board independence and labour productivity. However, Adewuyi et al (2009) for Nigeria observed an insignificant association between the two indicators. 
European Journal of Business and Innovation Research

Vol.8, No.2.pp. 30-47, April 2020

Published by ECRTD-UK

Print ISSN: 2053-4019(Print), Online ISSN: 2053-4027(Online)

\section{IMPLICATION TO RESEARCH AND PRACTICE}

The study showed that an increase in board size influences the productivity Nigerian firms positively but at a decreasing rate, indicating an optimal size hence the relationship between the two variables is quadratic in nature. In addition increase in the institutional investors and firm size enhance dependent variable. On the other hand, an increase in borrowing leads to decline in productivity. However, directors' shareholding, independent directors and independence of audit committee do not have influence on the dependent variable measured by labour productivity. This paper contributes to the body of knowledge by extending the number of years to thirty as against the average of ten years by previous studies. Labour productivity was also used as a measure of performance, which is not common among the emerging economies scholars including Nigeria.

To the best of knowledge of the researcher there is little or no empirical research that analyzes directly the relationship between governance and productivity of firms in Nigeria, except Adewuyi and Olowookere (2009) and Olowookere (2008). Studies in advanced countries have established that increase in productivity of firms influence financial performance positively. Therefore the limited empirical evidence of the effect of corporate governance on financial performance in Nigeria indicates an expected positive relationship between financial performance and productivity. Consequently, this study will be of great value to the operators who will be able to remove the shortcoming of financial and market measurements as proxies for firms' performance and improve the performance of firms through the use of productivity. It will also enhance shareholders value in form of cash and capital appreciation. Policy makers can also benefit from the study by reviewing the structure to incorporate the use of productivity as a measure to correct the lapses of finance and market as proxies for firm performance before the computation of either. Researchers also will find the study as a good point of reference for further study on the topic.

\section{CONCLUSION}

The study examined corporate governance practice and productivity of Nigerian listed firms from 1989 to 2018. Secondary data was collected using the financial statements of the selected firms and the Nigerian Stock Exchange Factbooks of various issues. The issue of inadequacies of finance and market based method of measuring performance of firms have been debated in literature as gauges usually lead inaccurate results. Consequently, this research makes use of labour productivity in order to resolve the impasse since it has been established by studies carried out in advance countries that there is a positive association between productivity and financial and market performances. Therefore, the study showed that three out of seven independent variables (board size, institutional investors and firm size) have positive influence on the labour productivity of Nigerian listed firms. On the other hand, leverage has negatively relationship while directors' shareholding, independent directors and independence of audit committee do not have influence on the dependent variable measured by labour productivity. The study recommends the use of labour productivity as a measure of firm performance in order to eliminate the shortcomings of financial and market values and improve shareholders wealth. 
European Journal of Business and Innovation Research

Vol.8, No.2.pp. 30-47, April 2020

Published by ECRTD-UK

Print ISSN: 2053-4019(Print), Online ISSN: 2053-4027(Online)

\section{References}

Adebiyi, W. K. (2017), Board composition and financial reporting quality of deposit money banks in Nigeria. International Journal of Innovative Finance and Economics Research, 5(4):97-104.

Adelegan, O. J (2007a) Corporate Governance in Nigeria. In Kostyuk, A.N, Braendle U,C and Apreda, R. (Ed.) Corporate Governance Virtus interpress: Ukraine.

Adelegan, O.J. (2007b). Board Changes and Efficiency of the Nigeria Stock Market In Corporate Board Role, Duties and Composition . Issue 2, Vol. 3. Virtus Interpress. Ukraine. 5.

Adenikinju, O \&. Ayonrinde, F. (2001). Ownership Structure, Corporate Governance and Corporate Performance: The Case of Nigerian Quoted Companies. AERC Biannual Research Workshop, Nairobi, May. 6.

Adewuyi, O. A. \& Olowookere, E.A. (2009), "Impact of governance instruments on the productivity of Nigerian listed firms", ICFAI University Journal of Corporate Governance, 8(3/4), 51-74.

Aebi, V., Sabato, G., \& Schmid, M. (2012) Risk management, corporate governance and bank performance in the financial crisis, Journal of Banking \& Finance 36(12), 3213.

Arellano, C., Yan B., \& Jing Z., (2012) "Firm dynamics and financial development," Journal of Monetary Economics, 59 (6), 533-549

Brown, L. D. \& Caylor, M.L. (2004) corporate governance and firm performance. Working Paper, Georgia State University, (Dec). 18.

Buera, F. J. \& Yongseok S., (2011) "Financial Frictions and the Persistence of History: A Quantitative Exploration," Journal of Political Economy, 121(2) ,22

Buera, F. J. \& Yongseok S., (2013) "Financial Frictions and the Persistence of History: A Quantitative Exploration" Journal of Political Economy,121(2),221-272.

Cadbury, A. (1992). The Code of Best Practice, Report of the Committee on the Financial Aspect of Corporate Governance. London: Gee and Co Ltd.

Chen, Z., Du, J., Li, D., \& Ouyang, R. (2013). Does foreign institutional ownership increase return volatility? Evidence from china. Journal of Banking \& Finance, 37(2), 660.

Coircelli, F., Driffield, N., Sarmistha, P. \& Isabelle R. (2012) "When does leverage hurt productivity growth? A firm-level analysis" Journal of International Money and Finance 31, 1674-1694.

Code of Corporate Governance for Public Companies in Nigeria (2003) www.sec.gov.ng

Companies and Allied Matters Act (1990) as amended

Cooley, T. F. \& Quadrini, V. (2001) "Financial markets and firm dynamics," American Economic Review, 1286-1310.

Core, J., Guay, W. \& Rusticus, T. (2005) Does Weak Governance Cause Weak Stock Returns? An Examination of Firm Operating Performance and Analysts' Expectation, University of Pennsylvania. 24.

Dalton, D. R., Daily, C. M., Johnson, J. L., \& Ellstrand, A. E. (1999). Number of directors and financial performance: A meta-analysis. Academy of Management Journal, 42(6), 674686.

Edmans, A, (2014) Blockholders and Corporate Governance (July 25). ECGI - Finance Working Paper No. 385. Available at SSRN: https://ssrn.com/abstract 2285781 
European Journal of Business and Innovation Research

Vol.8, No.2.pp. 30-47, April 2020

Published by ECRTD-UK

Print ISSN: 2053-4019(Print), Online ISSN: 2053-4027(Online)

Eisenhardt, K. M. (1989). Agency Theory: An Assessment and Review. Academy of Management Review 14 (1), 57-74 Retrieved from http://www.wikipedia 21/10/2015

Gaitán S. C., Herrera, H. \& Pablo E. (2017) Corporate Governance and its Effect on Productivity under Different Business Environments: Evidence from Latin America: https://www.researchgate.net/publication/318458086, retrieved on 12. 2. 2020

Gatti, R.; \& Love, I. (2006) "Does access to credit improve productivity? Evidence from Bulgarian firms" World Bank Policy Research Paper No. 3921.

Gbadebo, A. O. (2017) Effect of Corporate Governance Mechanisms on Performance of Listed Nigerian Firms, unpublished Ph. D. Dissertation, Nnamdi Azikiwe University Awka,

Gbadebo, A. O. (2016) Impact of Corporate Governance Mechanisms on Financial Performance of Deposit Money Banks in Nigeria Sahel Analyst: Journal of Management Sciences 14(5) 44-57 University of Maiduguri

Ghosh, S. (2009) "Productivity and financial structure: evidence from Indian high-tech firms" Global Business Review 10, 261-278

Girma, S., \& Vencappa, D. (2015) "Financing sources and firm level productivity growth: evidence from Indian manufacturing” Journal of Productivity Analysis 44, 283-292.

Gopinath, G., Sebnem K., Loukas K,, \& Carolina V., (2015) "Capital allocation and productivity in South Europe," Technical Report National Bureau of Economic Research

Gupta, M., \& Newalka, G. (2015). "Impact of Corporate Governance on the Profitability of a Firm": Empirical study on National Stock Exchange, 2nd International Conference of Science, Technology and Management, University of Delhi, India, 572-578.

Hassan, M.A. (2014) Employee Welfare Programme: Panacea Towards Improving Labour Productivity in the Service Sector in Nigeria, Mediterranean Journal of Social Sciences 5(10) 78-81

Hay, D. \& Morris, D. (1979) Industrial Economics: theory and evidence Oxford University Press.

Hill, C. \& Snell, S. (1989). Effects of Ownership Structure and Control on Corporate Productivity, Academy of Management Journal, 32, 25-46..

Khan, A. \& Thomas, J. K. (2013 ) "Credit Shocks and Aggregate Fluctuations in an Economy with Production Heterogeneity,” Journal of Political Economy, 121(6), 1055-1107.

K“oke, J. (2001), Corporate governance, market discipline, and productivity growth Centre for European Economic Research Mannheim, Germany, ZEW Discussion Paper No. 01-55 ftp://ftp.zew.de/pub/zew-docs/dp/dp0155.pdf, retrieved on January 15, 2020

Kyereboah-Coleman, A., \& Nicholas- Biekpe, N. (2005). "Corporate Governance and the performance of Microfinance Institutions (MFIs) in Ghana”, Working paper 4330-05, UGBS, Legon

Leung, D., Meh, C. \& Terajima, Y.. (2008a) "Are There Canada-U.S. Differences in SME

Lawal, B. (2012). 'Board dynamics and corporate performance: Review of literature, and empirical challenges', International Journal of Economics and Finance, 4(1), 22-35. Financing?" Bank of Canada Working Paper No. 2008-41.

Leung, D., C. Meh, and Y. Terajima. (2008b) Productivity in Canada: Does Firm Size Matter? Bank of Canada Working Paper. Bank of Canada Review • Autumn 5-14

Li, H. (2016) Leverage and Productivity, Federal Reserve Bank of San Francisco https://sites.google.com/site/tohuiyu/. email: tohuiyu@ gmail.com retrieved 24.2.2020 
European Journal of Business and Innovation Research

Vol.8, No.2.pp. 30-47, April 2020

Published by ECRTD-UK

Print ISSN: 2053-4019(Print), Online ISSN: 2053-4027(Online)

Magbagbeola, N.O. (2005). Governance Structure, Managerial Characteristics and Firm Performance in the Nigerian Banking Industry . Final Report Submitted to the AERC, South Africa (Dec). 55

Min B. S. \& Smyth R., (2014) corporate governance, globalization and firm productivity Journal of World Business 49(3), 372-385

Mnasri, K., \& Ellouze, D. (2015) ownership structure, product market competition and productivity Management Decision, 53(8), 1771-1805.

Moses, T. (2019), Board characteristics, audit committee composition, and financial reporting in Nigeria. International Journal of Innovative Social Sciences \& Humanities Research, 7(1), 37-45

Mousa, G.A. \& Desok, A.M. (2012). The Association between Internal Governance Mechanisms and Corporate Value: Evidence from Bahrain, Asian Academy of Management Journal of Accounting and Finance, 8(1), 67-91

Mundakkad, P (2018) Firms' leverage and labour productivity: a quartile regression approach Economics Bulletin, Volume 38(4), 2331-2344

Musso, P. \& Stefano S. (2008) "The impact of Financing constraints on Firm survival and growth" Journal of Evolutionary Economics 18, 135-149.

Nucci, F., Pozzolo, A. \& Schivardi, F. (2005) "Is firms' productivity related to its financial structure? Evidence from microeconomic data" Rivista di Politica Economica, SIPI Spa 95, 269-290.

Nickell, S. \& Nicolitsas, D. (1999) “How does financial pressure affect firms?" European Economic Review 43, 1435-56.

Nunes, P.; Sequera, T. \& Serrasqueiro, Z. (2007) "Firms' leverage and labour productivity: a quantile approach in Portugese firms" Applied Economics 39, 1783-1788.

OECD, (2001). Organisation for Economic Cooperative Development (OECD), Principles of Corporate Governance. Paris: Organisation for Economic Cooperative Development.

Olowookere, E .A. (2008). Corporate Governance and Firm Performance: The Case of Nigerian Listed Firms, unpublished M.Sc. Dissertation, University of Ibadan.

Reddy, K., Locke, S., Scrimgeour, F., \& Gunasekarage, A. (2008). Corporate governance practices of small cap companies and their financial performance: An empirical study in New Zealand. International Journal of Business Governance and Ethics, 4(1), 51

Renneboog, L. (2000) "Ownership, Managerial Control and the Corporate Governance of Companies n Listed on the Brussels Stock Exchange.” Journal of Banking and Finance, 24, 1959-1995

Roslas, L. (1948), International Comparison of Productivity International Labour Review 18, 95

Rubin, A., \& Smith, D. R. (2009). Institutional ownership, volatility and dividends. Journal of Banking and Finance, 33(4), 627.

Sanda, A., Mukailu, A.S. \& Garba, T. (2005). Corporate Governance Mechanisms and Firm Financial Performance in Nigeria. AERC Research Paper 149. 73

Sanusi, J. O. (2002). Promoting Good Corporate Governance in Nigeria: Issues and Challenges. Presented at the 2002 Directors' Seminar organized by Financial Institute Training Center, Nigeria on 4-6 June. 
Vol.8, No.2.pp. 30-47, April 2020

Published by ECRTD-UK

Print ISSN: 2053-4019(Print), Online ISSN: 2053-4027(Online)

Schiantarelli, F. \& Sembenelli, A. (1997) "The maturity structure of debt-determinants and effects on firms' Performance" World Bank Policy Research” Working Paper No.1699.

Schotter, A. (2001). Microeconomics: A Modern Approach $3^{\text {rd }}$ Edition. Addison-Wesley Longman: New York. 74.

Senbet, I. W., \& John, K. (1998). "Corporate Governance and Board Effectiveness", Journal of Banking and Finance 22 (May), 371 -403

Setia-Atmaja, L. (2009) Governance mechanisms and firm value: The impact of ownership concentration and dividends. Corporate Governance: An International Review, 17(6), 694-709

Shan, Y. G., \& McIver, R. P. (2011) corporate governance mechanisms and financial performance in china: Panel data evidence on listed non-financial companies. Asia Pacific Business Review, 17(3), 301

Tian, G. Y., \& Twite, G. (2011). corporate governance, external market discipline and firm productivity Journal of Corporate Finance, 17(3), 403

Udo-Aka, U. (1983) Measuring Productivity Issues and Problems, in Osoba, A. M. (ed.): Productivity in Nigeria, Proceedings of National conference: Ibadan, NISER

Wilson, I. (2006). Regulatory and Institutional Challenges of Corporate Governance in Nigeria Post Banking Consolidation. Nigerian Economic Summit Group Economic Indicators, April-June, 12(2) 79.

$\mathrm{Xu}, \mathrm{X}$. and Y. Wang. (1999) "Ownership Structure, Corporate Governance, and Firms' Performance: The Case of Chinese Stock Companies." Working Paper, World Bank

Yermack, D. (1996), Higher market valuation of a company with a small board of directors, Journal of Financial Economics 40, 185-211. 